\title{
TECHNOLOGY DEVELOPMENT IN CONSTRUCTION: A CONTINUUM FROM DISTANT PAST INTO THE FUTURE
}

\author{
Mirosław J. Skibniewski ${ }^{1}$, Edmundas K. Zavadskas ${ }^{2}$ \\ ${ }^{1}$ Department of Civil \& Environmental Engineering, University of Maryland, \\ College Park, MD 20742-3021, USA \\ ${ }^{2}$ Faculty of Civil Engineering, Vilnius Gediminas Technical University, \\ Saulètekio al. 11, 10223 Vilnius, Lithuania \\ E-mails: ${ }^{1}$ mirek@umd.edu; ${ }^{2}$ edmundas.zavadskas@vgtu.lt (correspondingauthor) \\ Received 30 Nov. 2012; accepted 03 Dec. 2012
}

\begin{abstract}
This paper deals with the historical and current trends in the development of civil engineering and construction technologies. The authors demonstrate the continuity of creative thought and effort among early master builders and technology developers throughout the history of civilizations that created the most iconic structures remaining in the world heritage of the built environment to the contemporary times. Recent concepts and ongoing efforts in the development of advanced construction technologies based on automation and information sciences, materials science and systems engineering are highlighted in the context of historical ideas and achievements of past architects and construction engineers of the past century.
\end{abstract}

Keywords: civil engineering, construction technology, creativity, technology perspective.

\section{Introduction}

Technology is the making, modification, usage, and knowledge of tools, machines, techniques, crafts, systems, methods of organization, in order to solve a problem, improve a preexisting solution to a problem, achieve a goal or perform a specific function. It can also refer to the collection of such tools, machinery, modifications, arrangements and procedures. Technologies significantly affect human as well as animal species' ability to control and adapt to their natural environments (Wikipedia 2012). Technology plays an important role in the science $\rightarrow$ technology $\rightarrow$ production $\rightarrow$ economy chain (Fig. 1).

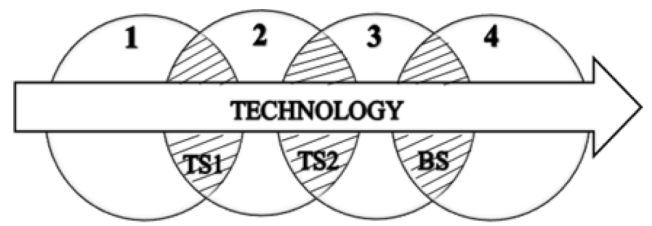

Fig. 1. Location of technology in the production chain of science-technique-trade-economics. TS-1 - technological sciences, TS-2 - technological systems, BS - business systems: 1 science, 2 -technique, 3 -production, 4 -economics

Technology, as a scientific discipline, is determined to be transmission between the production and the fundamental sciences. Technology of construction processes analyses the separate elements of construction production (Fig. 2). The main objectives of technological sciences in the realm of construction are as follows:
- Systems-oriented analysis of construction processes with aspiration to determine their main components and relationships;

- Development of standard construction processes to be emulated throughout the industry;

- Research-based compilation of data for use in technology standards, directories and databases.

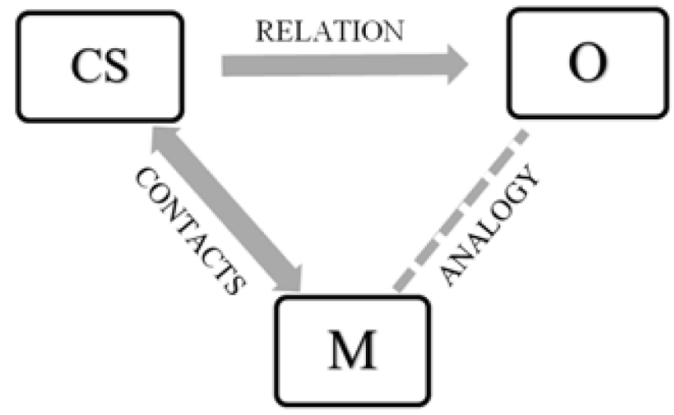

Fig. 2. The principal scheme of construction process modeling. $\mathrm{CS}$ - cybernetic system, $\mathrm{O}$ - object, $\mathrm{M}$ - model

A typical feature of most if not all construction technologies is their implementation of achievements originating from different scientific disciplines. The modelling of construction process is one prominent example of this fact (Fig. 3). The main components of the model are: pre-construction/ preparation processes (PP), construction site processes (CP) and management of the construction process (MP) (Fig. 4) (Fiedler et al. 1981). 


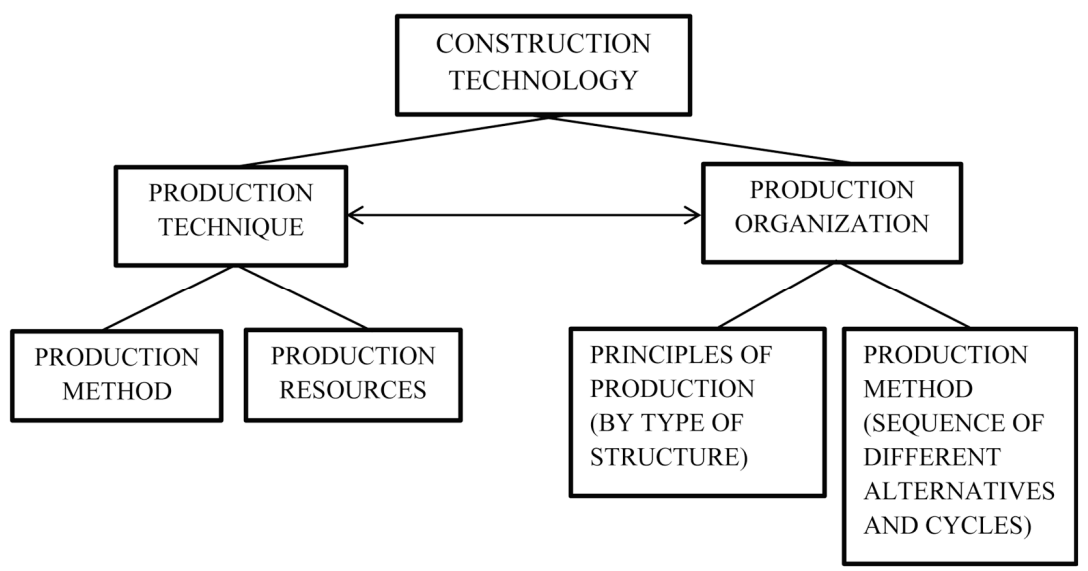

Fig. 3. Research objectives related to construction processes (technology)

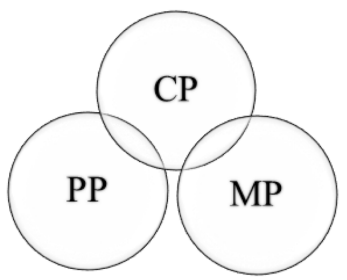

Fig. 4. Modeling components of construction technological processes: PP - pre-construction/ preparation processes, CP construction processes, MP - management processes

Future development of construction technologies depends on the most pressing needs of sustainable built environment, economic and business fragmentation constraints characteristic for the construction industry, and the need to increase productivity and safety of construction workers. A systematic approach to the prediction of future trends has been provided by Zavadskas et al. (2007).

\section{Creativity and Technology}

What is creativity? According to a popular reference article, the term "refers to the invention or origination of any new thing (a product, solution, artwork, literary work, etc.) that has value. "New" may refer to the individual creator or the society or domain within which novelty occurs. "Valuable", similarly, may be defined in a variety of ways. The range of scholarly interest in creativity includes a multitude of definitions and approaches involving [...] psychology, cognitive science, education, philosophy (particularly philosophy of science), technology, theology, sociology, linguistics, business studies and economics, taking in the relationship between creativity and general intelligence, mental and neurological processes associated with creativity, the relationships between personality type and creative ability and between creativity and mental health, the potential for fostering creativity through education and training, especially as augmented by technology, and the application of creative resources [...]." (Wikipedia 2012).

There are over 200 scientific descriptions of the process of human creativity due to the numerous aspects, domains and manifestations of this attribute. The role of creative minds in the construction industry will be of vital importance in the future, as this industry is most often the largest contributor to the national economies of almost all developed nations and beyond (Langford, Dimitrijević 2002).

In construction, creativity has been associated in history in a large part with the intellectual and organizational capacities of the 'master builder' (Skibniewski 2012). Creativity remains unrealized unless it leads to the act of innovation. As construction knowledge, technology and experience progressed through the ages in the realization of major construction projects, various projectrelated specialties emerged: architects, building technicians and engineers, project sponsors and financiers, material and equipment suppliers, labor organizers, etc. This has often led to creative tensions among numerous project participants which either stimulated or hampered construction creativity and innovation.

As of 23 November 2012, more than 1200 scholarly papers related to the topic of "Technology \& Creativity" can be found in the Thomson Reuters Web of Science database (Fig. 5). However, the number of related publications dealing with "civil engineering" and "construction and building technology" amounts to only several dozen. A sample of interesting examples of such papers is presented in Table 1.

\section{Historical Retrospective}

Construction is undoubtedly a product of human creativity which experienced its 'peaks and valleys' over the centuries. Building technologies and trades developed at first, most likely in ancient Mesopotamia (in the TigrisEuphrates river system), dating back to year 3600 BC. According to Sumerian mythology, the Mesopotamians regarded the craft of building as a divine gift taught to men by the gods. Ziggurats, pyramid-like structures of that civilization, remain to this day in today's Iraq. Similarly, ancient Chinese construction methods, utilizing both stone and timber, are as old as the Chinese civilization, dating back approximately to year $4000 \mathrm{BC}$. The Chinese were using elaborate wall-building techniques since approximately year $800 \mathrm{BC}$, culminating in the Great Wall of China built over an extraordinarily long period of approximately 2000 years. Ancient Egyptian pyramids of Giza, whose construction lasted only approximately 20 years and concluded in approximately year 
$2560 \mathrm{BC}$, were initially 147 meters in height and remained the tallest man-made structures for over 3800 years. The exact means and methods of their construction, ranging from ancient forms of in situ processes to those partially resembling offsite prefabrication, are subject to protracted speculations to date among archeologists and historians of technology. Ancient Maya construction of Central America, featuring ceremonial platforms, palaces, pyramids, temples, observatories and ball-courts had intricate carved stones and stair-step design, spanning a vast period of several thousands of years. Elaborate building methods were developed to include massive substructures made of stucco and cut stone interior, providing a solid foundation for the ensuing superstructures. External aesthetics took precedence over utility of many of these structures, as their purpose was typically both religious and lay. Ancient Inca architecture in pre-Columbian South America featured in Cuzco and at the royal estate of Machu Picchu dates back to the $2^{\text {nd }}$ century BC and has not been emulated for several centuries following the Spanish conquest and subsequent destruction of this civilization.

Ancient Greece and ancient Roman Empire borrowed a number of building techniques from the preceding civilizations while also developing unique techniques and architectural styles of their own, characterized by numerous temples, palaces and other public and private buildings, as well as world-renown structures such as Parthenon in Athens or Colosseo stadium in Rome. Construction techniques of parabolic stone arches subjected to compression forces only, with no bending moments, and the design and construction of elevated municipal

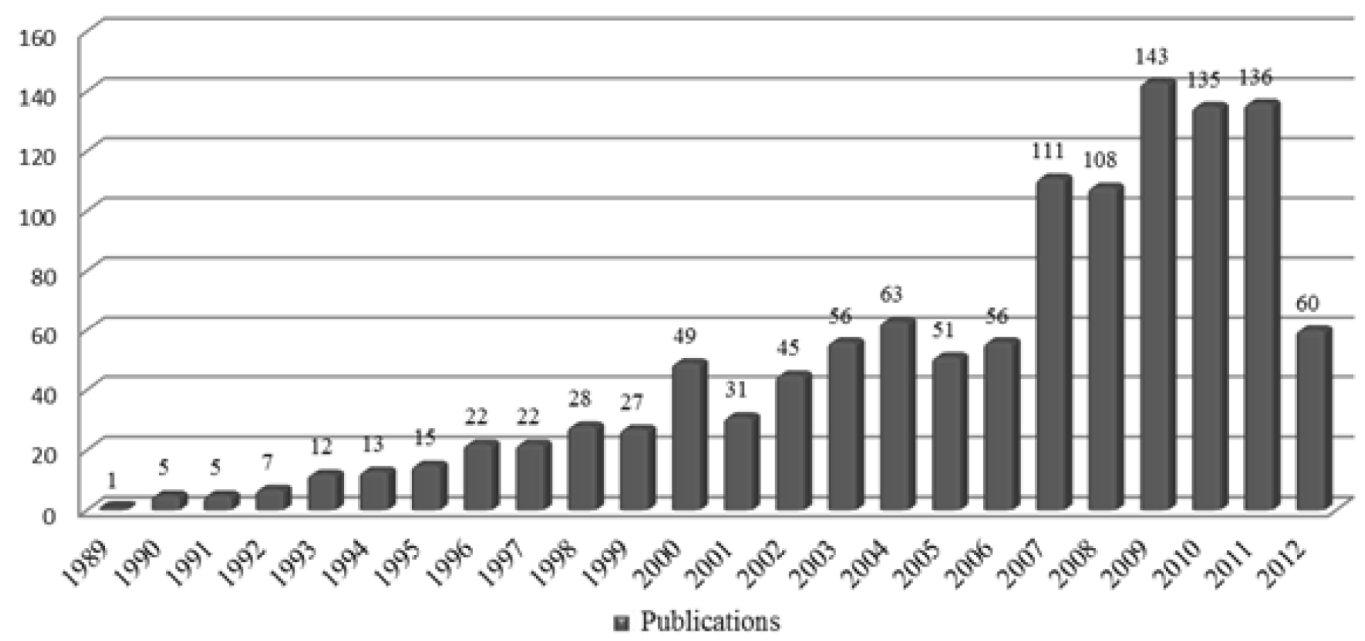

Fig. 5. Number of publications on the topic technology and creativity

Table 1. Sample publications on creativity and technology in civil engineering and construction

\begin{tabular}{l|l}
\hline \multicolumn{1}{c|}{ Reference } & \multicolumn{1}{c}{ Main topic } \\
\hline Noor 2011 & Intelligent adaptive Cyber-Physical Ecosystem \\
\hline Ibrahim et al. 2010 & Comparison CAD and manual sketching tools for teaching architectural design \\
\hline Lainez et al. 2009 & The Key-role of Eladio Dieste for Brickwork to Architectural design \\
\hline Kicinger et al. 2005 & Evolutionary computation and structural design \\
\hline Srdic, Selih 2011 & Integrated quality and sustainability assessment \\
\hline Peldschus, Zavadskas 2012 & Equilibrium approaches for construction processes \\
\hline Barrow 2006 & Ideation and CADCAM \\
\hline Holland 2006 & Virtual school of architecture and design \\
\hline Fan 2009 & Exploration and Practice in Design \\
\hline Negoescu, Axinte 2007 & Engineering for strategic advantages \\
\hline Seghedin 2007 & Combinatorics in technical creation \\
\hline Allen, Self 2008 & Analysis of the integration of knowledge \\
\hline Mackechnie, Buchanan 2012 & Creative Laboratory Model for Large Undergraduate Engineering Classes \\
\hline Zheng et al. 2011 & Impact of Nanotechnology on Future Civil Engineering Practice \\
\hline Brühwiler 2011 & New Swiss Codes for engineering \\
\hline Mashood et al. 2007 & KB-GA-Based Hybrid System for Layout Planning \\
\hline Ediz, Cagdas 2007 & Computational Architectural Design Model \\
\hline Sarrade et al. 2007 & The GENHEPI Concept \\
\hline Kaklauskas et al. 2011 & Integrated model and system for passive houses \\
\hline Zavadskas et al. 2011 & Intelligent library and tutoring system at all stages of a building life cycle \\
\hline Banaitiene et al. 2008 & Evaluating the life cycle of a building \\
\hline
\end{tabular}


and rural aqueducts resulted in great architectural accomplishments existing in southern and Western Europe to the present day. The following European era of the Middle Ages, which lasted longer than all of the subsequent cultural periods combined, resulted in splendid Romanesque and Gothic architecture demanding new projects, undertaken both with the use of proven construction techniques from the bygone eras and new materials and techniques, including the production and implementation of building glass and an apparent use of organic mortars for stone masonry.

\section{Linking the Present to the Past}

The invention of Portland cement and the production of concrete revolutionized the use of construction materials and techniques and the ensuing construction methods dominate to this day. There is some historical evidence that this technology dates back to the ancient Romans and was used in the Roman Empire, e.g. for construction of the Roman Pantheon (Mukerji 2005). However, with the demise of that empire, the use of concrete was abandoned and almost forgotten, until its re-invention and slow reemergence from the $18^{\text {th }}$ century AD onwards. Currently the tallest building in the world, Burj Khalifa in Dubai (828 meters tall) is built with the use of this material.

Ingenious creativity of construction craftsmen was exhibited throughout all of the architectural styles constituting the architectural and building engineering history of the last three centuries. Examples of ingenuity are too numerous to enumerate in a short presentation; it should suffice to mention the historically, technically, and artistically diverse select, short list of geniuses of Apollodorus of Damascus ( $2^{\text {nd }}$ century AD), Abbot Suger $\left(12^{\text {th }}\right.$ century), Villard de Honnecourt (13 ${ }^{\text {th }}$ century), Filippo Calendario $\left(14^{\text {th }}\right.$ century), Leonardo da Vinci $\left(15-16^{\text {th }}\right.$ centuries), Raphael Santi (16 ${ }^{\text {th }}$ century), Gianlorenzo Bernini $\left(17^{\text {th }}\right.$ century), Nicolai Eigtved (aka Niels Madsen) and Domenico Merlini (1 $8^{\text {th }}$ century), Bela Lajta and Adolf Lang $\left(19^{\text {th }}-20^{\text {th }}\right.$ centuries), Frank Lloyd Wright (early $20^{\text {th }}$ century), Renzo Piano $\left(20^{\text {th }}-21^{\text {st }}\right.$ centuries), Zygmunt Skibniewski $\left(20^{\text {th }}\right.$ century), Frank Gehry $\left(20^{\text {th }}-\right.$ $21^{\text {st }}$ centuries), and many others.

More than 20,541 scholarly papers published to date deal with the development of technology. The number of such publications is ever increasing (Figs 6 and 7). However, the number publications devoted to the subject of "civil engineering" or "construction and building technology" is only slightly more than 250 , or about one per cent of the total. Several new examples of such publications are presented in Table 2.

More than 4,092 scholarly publications are devoted to future technological developments (Web of Knowledge - Web of Science, 12/11/2012) (Fig. 8). In the same realm, the number of publications dealing with development of construction technologies is only 130 (Fig. 9). Some of the latest such publications are presented in Table 3.

A new impetus to creativity in construction, and particularly to large earthwork projects and to tall buildings, was the progress of construction mechanization
Table 2. Publications in Web of Science by topic: technology perspective

\begin{tabular}{|c|c|}
\hline Reference & Topic addressed \\
\hline Yang et al. 2012 & $\begin{array}{l}\text { Web-based evaluation system } \\
\text { housing }\end{array}$ \\
\hline Arslan 2012 & $\begin{array}{l}\text { Web-Based Contractor Evaluation } \\
\text { System for Mass-Housing Projects }\end{array}$ \\
\hline $\begin{array}{l}\text { Boukhatem et al. } \\
2011\end{array}$ & $\begin{array}{l}\text { Application of new information } \\
\text { technology on concrete }\end{array}$ \\
\hline Podvezko et al. 2010 & $\begin{array}{l}\text { Complex evaluation of contracts for } \\
\text { construction }\end{array}$ \\
\hline $\begin{array}{l}\text { Radziszewska-Zielina } \\
2010\end{array}$ & $\begin{array}{l}\text { Selecting the best partner construc- } \\
\text { tion enterprise in terms of partnering } \\
\text { relations }\end{array}$ \\
\hline Zhang, Hu 2011 & $\begin{array}{l}\text { BIM- and 4D-based integrated solu- } \\
\text { tion of analysis and management for } \\
\text { conflicts and structural safety prob- } \\
\text { lems during construction }\end{array}$ \\
\hline Dejus 2011 & Safety of technological projects \\
\hline Lee et al. 2012 & $\begin{array}{l}\text { A BIM- and sensor-based tower } \\
\text { crane navigation system }\end{array}$ \\
\hline Chow et al. 2012 & $\begin{array}{l}\text { Catastrophe model of withdrawal in } \\
\text { construction project dispute negotia- } \\
\text { tion }\end{array}$ \\
\hline Razavi, Haas 2012 & $\begin{array}{l}\text { A Reliability-Based Hybrid Data } \\
\text { Fusion Method for Adaptive Loca- } \\
\text { tion Estimation in Construction }\end{array}$ \\
\hline Hartmann 2011 & Project Teams \\
\hline AbouRizk et al. 2011 & Construction Engineering Operations \\
\hline
\end{tabular}

Table 3. Examples of latest publications, topic: technology possible way

\begin{tabular}{l|l}
\hline \multicolumn{1}{c|}{ Reference } & \multicolumn{1}{c}{ Considered problem } \\
\hline $\begin{array}{l}\text { Clements-Crowne } \\
\text { Ghaffarian Hoseini }\end{array}$ & Sustainable intelligent buildings \\
\hline Ecologically sustainable design \\
\hline Bhatla et al. 2012 & $\begin{array}{l}\text { Evaluation of accuracy of as-built } \\
\text { 3D modeling from photos taken by } \\
\text { handheld digital cameras }\end{array}$ \\
\hline Promis et al. 2012 & $\begin{array}{l}\text { Effect of post-tensioning on the } \\
\text { bending behavior }\end{array}$ \\
\hline Gong et al. 2012 & $\begin{array}{l}\text { GPS/GIS method for travel mode } \\
\text { detection in New York City }\end{array}$ \\
\hline Zalama et al. 2011 & $\begin{array}{l}\text { An Effective Texture Mapping } \\
\text { Approach for 3D Models Obtained }\end{array}$ \\
\hline Chu et al. 2011 & $\begin{array}{l}\text { Development of Microbial Geotech- } \\
\text { nology }\end{array}$ \\
\hline Marti et al. 2010 & $\begin{array}{l}\text { A multi-agent system for managing } \\
\text { adverse weather situations }\end{array}$ \\
\hline Bayart et al. 2010 & $\begin{array}{l}\text { A Framework for Assessing } \\
\text { Off-Stream Freshwater }\end{array}$ \\
\hline Yang, Lin 2011 & $\begin{array}{l}\text { Coastal Reservoir by Soft-Dam and } \\
\text { its Possible Applications }\end{array}$ \\
\hline
\end{tabular}

spurred by the invention of steam engine. Much of such equipment has been preserved to this day, thanks to the efforts of the Historical Construction Equipment Association (Historical Construction Equipment Association 2012) based in Ohio, USA. A revolution in construction equipment was started with the invention of hydraulic pistons for the transmission of large forces. This led to a series of highly successful designs of the new types of 


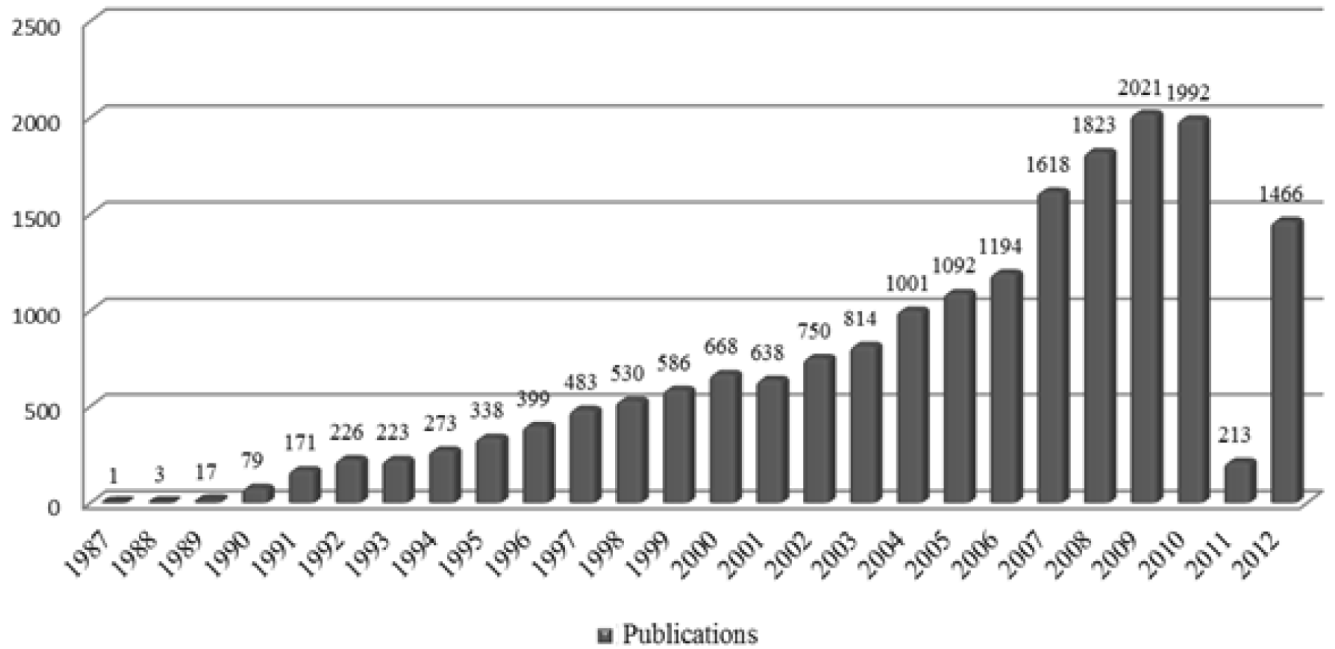

Fig. 6. Publications in Web of Science on topic: technology perspective

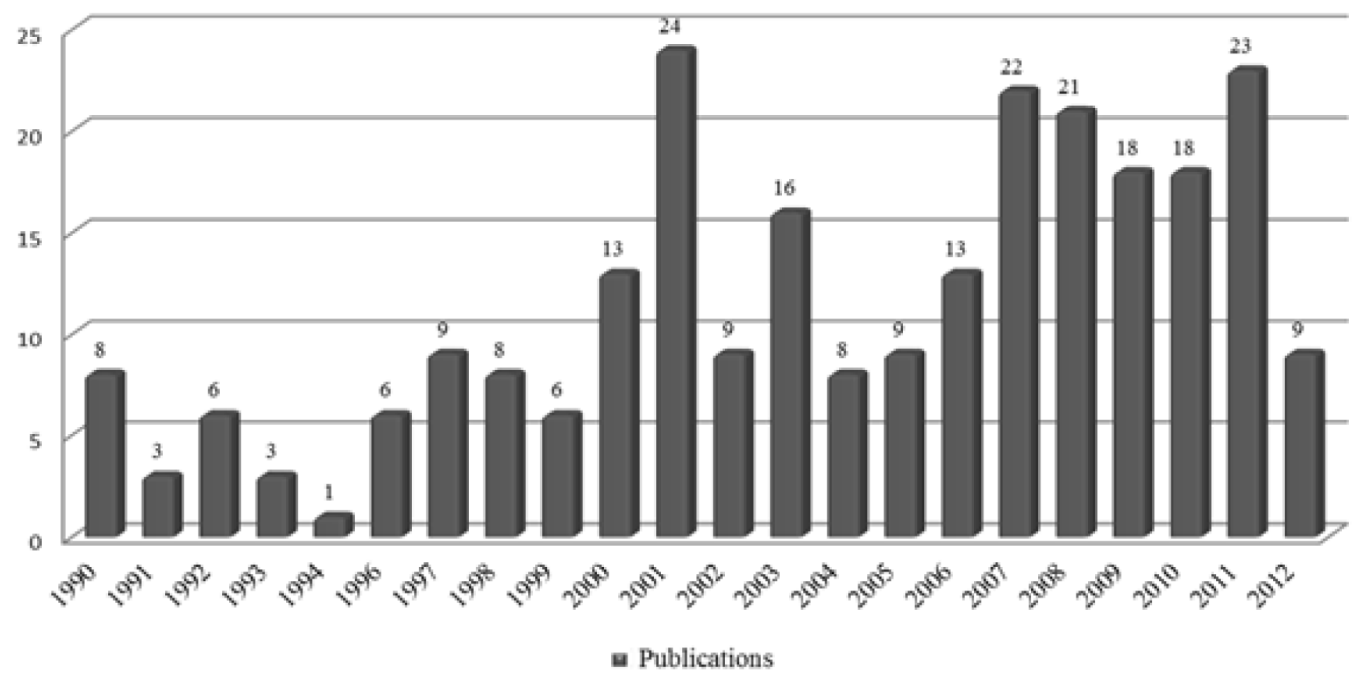

Fig. 7. Publications by topics: technology perspective (science categories - engineering civil or construction building technology)

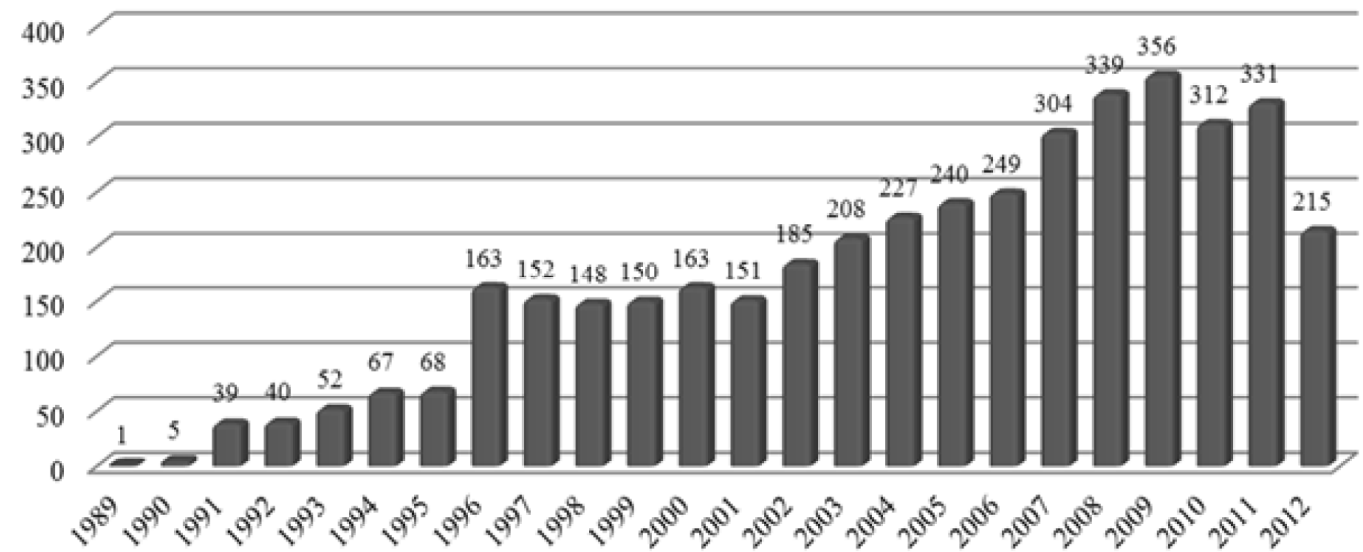

Fig. 8. Publications by topic: technology possible way 


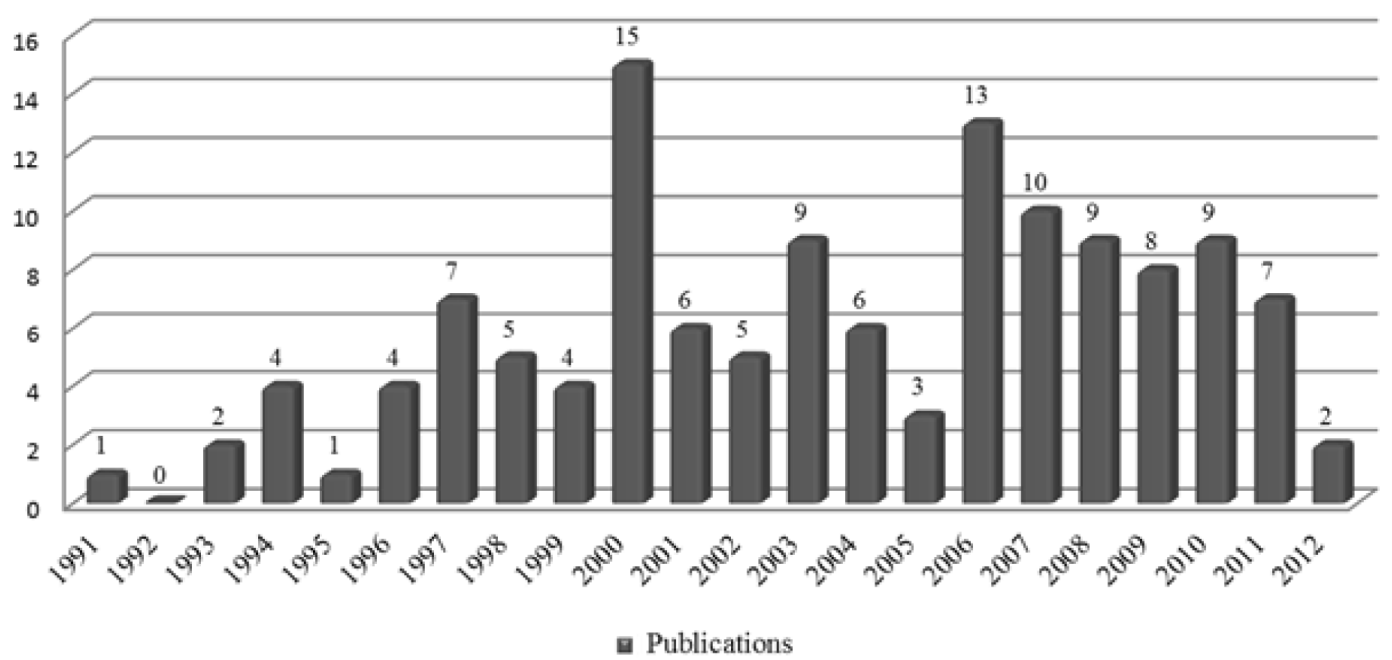

Fig. 9. Number of publications by topic: technology possible way (science categories: construction technology or civil engineering)

earthmoving equipment, surface finishing tools, and all terrain telescopic boom cranes (Skibniewski 1988a). What followed years later are improved equipment controls, intelligent sensors, laser-based telemetry and global positioning systems that led to marked improvement in the quality and productivity to many types of earthwork and allied construction tasks (Skibniewski 1993). Subsequently, construction robotics were designed and prototyped, initially in the early 1970's in the former Soviet Union on commission from the former Soviet armed forces (Springer Handbook of Mechanical Engineering 2009) (e.g. Dr. G. Frenkel at Moscow State University of Civil Engineering, formerly Moscow Civil Engineering Institute) and at VNIISTROYDORMASH), then in the late 1970's and early 1980's in Japan (Prof. Y. Hasegawa at Waseda University's Systems Science Institute, followed by several construction firms such as Obayashi, Shimizu, Kajima, Takenaka, Fujita, and others) and in the United States (Prof. W. Whittaker at Carnegie Mellon University's Field Robotics Center) (Haas et al. 1995). The idea was not entirely new, as already in 1910 a French artist Villemard produced a postcard illustration depicting his vision of a construction site in the year 2000, see Fig. 10 (BLDG BLOG 2011). International Association for Automation and Robotics in Construction (IAARC) (International Association for Automation and Robotics in Construction 2012) was created in 1993, continuing to organize annual symposia on this subject held around the world since 1984. (2012 and 2013 International Symposia on Automation and Robotics in Construction 2012). In its early years of existence, IAARC members unknowingly shared Villemard's early vision that robotics will become commonplace on construction project sites in the developed economies by the year 2000 , which has not materialized not because of the lack of technical capabilities to implement them, but mainly due to the protracted economic crisis in Japan which led the development of robotic prototypes and automated systems for construction sites between in the 1980's and 1990 's, and the persisting fragmentation of the industry in the United States and western Europe in their methods of the delivery of projects (Skibniewski 1988b).

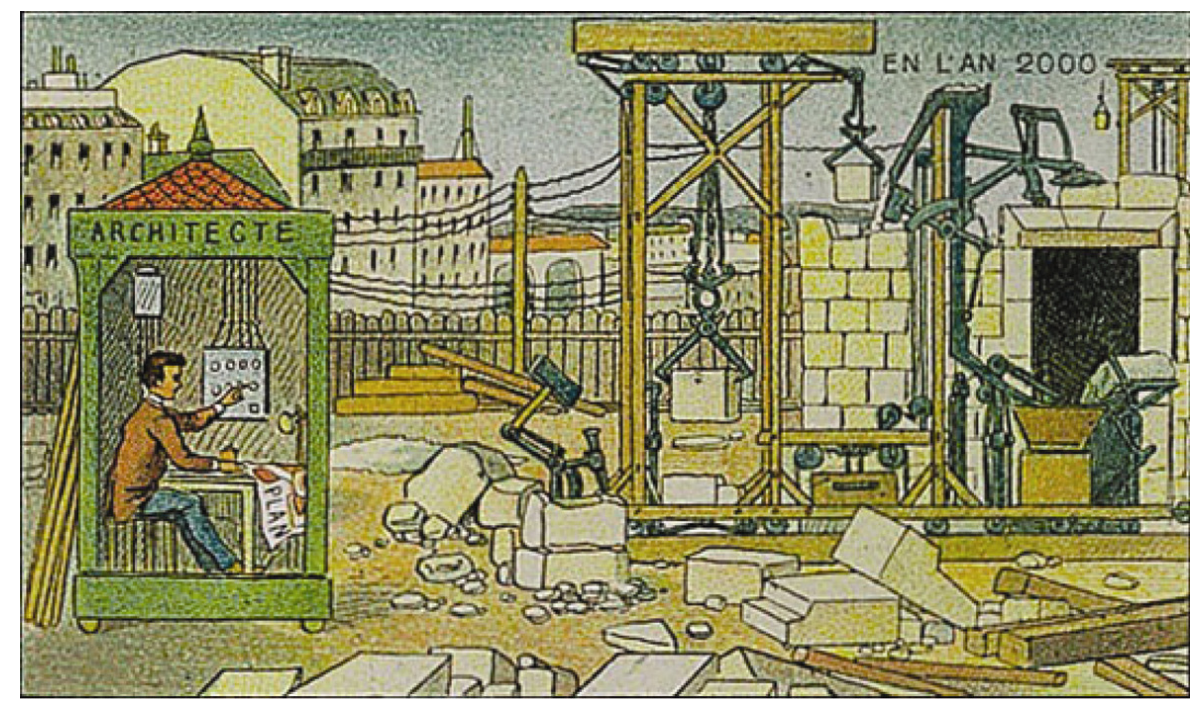

Fig. 10. Villemard's 1910 vision of a robot on a building construction site 
Tall building construction presented yet another set of challenges to construction creativity, particularly related to vertical transport (National Institute of Building Science 2012) elevator technologies available today widely employ artificial intelligence and fuzzy-set-based controls to automate and optimize vertical transport of materials and people. This, combined with significant improvements in lifting crane equipment and operations, has led to increased efficiency, safety and improved productivity on the construction site, although accidents in this type of essential construction work as still relatively common (Crane Accidents 2012) There is a need redesign of many construction tasks based on sound ergonomic principles and aimed at further mechanization and automation of tasks that are simple, repetitive and inherently dangerous (Russell, Skibniewski 1990).

Recent advances in the implementation rapid prototyping, construction process simulation and accelerated implementation of Building Information Modeling (BIM) technologies are on their way to transforming building construction and allied project-based professions serving the construction industry (Building SMART International Ltd 2012; National Institute of Building Sciences 2012; Zavadskas 1991; Kanapeckiene et al. 2011; Zavadskas et al. 1995, 1994; Zavadskas, Kaklauskas 2007; Popov et al. 2010; Skibniewski, Jang 2009).

\section{Innovation Environment in Construction Technology and Possible Way Forward}

Innovation in construction project management benefitted much from the early advances in computational science and information technologies dating back to the late 19th century, particularly from work flow and networking techniques leading to improved project scheduling (Marsh 1975; Hajdu 1997). Program management to reshape the future built environment (Kaklauskas, Zavadskas 2009), particularly that of 21 st cities, will depend on our ability to implement the latest advances of information and automation technologies in an integrated manner (Skibniewski et al. 1997; Sawaf, Skibniewski 2011; Kaklauskas et al. 2010, 2011, 2012; Zavadskas 2010).

Decision making will play a crucial role in construction management. Multi-Criteria Decision Making (MCDM) (Koksolan et al. 2011) is a sub-discipline of operations research that explicitly considers multiple criteria in decision-making environments, which can help the stakeholders: (a) assess the current situation, (b) find satisfactory solutions, and (c) take appropriate responses taking into account a set of objectives and criteria, that can be conflicting, multidimensional, incommensurable and incomparable. MCDM involves diverse methods leading to the prototyping and implementation of decision aid tools (Skibniewski, Chao 1992; Zavadskas et al. 1994, 2011; Yu, Skibniewski 1999; Zavadskas, Turskis 2011; Jiang et al. 2012; Bitarafan et al. 2012; NietoMorote, Ruz-Vila 2012).

It is widely acknowledged that the main barrier to an increased pace of innovation in construction is the fragmentation of this industry initiated in mid 1950's and exacerbated throughout the remainder of the 20th century, creating adversarial and litigious project execution environments. Intense competition in most developed markets and the consequential low profit margins for construction contractors, designers and suppliers led to the commoditization of this industry. Additional severe challenges to the construction industries exist in the newly developing markets and in transition economies (Kocsis et al. 2011). Much of the process and quality improvement in construction utilizes proven management concepts from industries outside of construction (Tchidi et al. 2012). However, new project delivery systems such as Build-Operate-Transfer afforded an opportunity for new synergies among project owners, financiers, designers, constructors, suppliers and facility operators (Salman et al. 2007).

Supply chains in construction are being transformed thanks to implementation of successful ideas from retail trade industries (Li et al. 2008) and e-commerce platforms affording access to previously closed markets and increasing competitiveness among suppliers (CastroLacouture et al. 2007). Development of Internet-based collaboration tools, besides their overwhelmingly positive effect on project efficiency and productivity, created also a highly distributed construction project management environment (Nitithamyong, Skibniewski 2004; Urbanaviciene et al. 2009; Costa, Tavares 2012; Kaklauskas, Zavadskas 2002, 2010, 2012). Intelligent materials, distributed sensor systems and nanotechnology create new opportunities beyond the conventional solutions possible with traditional construction materials and systems (Mann 2006).

Schug and Watson of FMI argue for the need of construction innovation at three levels: tactical, operational and strategic (Schug, Watson 2012). They state that routine perspectives brought into construction from outside industries generate stimulation that drives innovation. Such innovation must be rewarded by recognition from industry peers (Construction Week Online 2012). All project participants should be made aware of their surroundings, enabling them to sense change and communicate the information to leaders of their organizations about technical and other related changes as seen from their perspective. Shared visions are essential to motivate and inspire construction organizations, propelling them to higher levels of creativity and innovation. Development of new skills, systems and strategic awareness creates a gradual change in attitude and behavior, resulting in improved organizational culture facilitating employee creativity. Changing the company culture to facilitate greater creativity takes time for most contractors due to organizational inertia and risk aversion created by the competitive and litigious work environment.

A number of organizations worldwide, such as Construction Industry Institute, (Construction Industry Institute 2012) FIATECH, (Fiatech 2012) Construction Innovation Forum, (The Construction Innovation Forum 2012) Building Smart Alliance, (The building SMART alliance 2012) and others strive to foster the culture of creativity and innovation in the construction industry 
(Skibniewski, Chao 1992; Chao, Skibniewski 1995). Creativity unleashed by the use of innovative technologies can transform the entrenched relationships among project participants throughout the entire supply chain of this industry. This requires technology transfer from other branches of industry into construction and vice versa, (Skibniewski, Nof 1989; Pan et al. 2011; Kaklauskas, Zavadskas 2004) with a thorough technology feasibility evaluation prior to its implementation on construction sites (Gaultney et al. 1989; Jiang et al. 2012). Much of the current efforts focus on construction innovation aims at the challenges related to environmental sustainability and energy management in the built environment, (Kaklauskas et al. 2012; Zavadskas et al. 2008; Turskis et al. 2012) safety improvement, (Cheng, Teizer 2011) and productivity enhancement (Chao, Skibniewski 1994; Liao et al. 2012; Zavadskas, Vaidogas 2009). This trend, in addition to creativity manifestations in new architectural forms, is likely to continue well into the future, particularly over growing environmental protection concerns and sustainability of the current economic systems in the remainder of the 21 st century.

\section{References}

AbouRizk, S.; Halpin, D.; Mohamed, Y.; Hermann, U. 2011. Research in modeling and simulation for improving construction engineering operations, ASCE Journal of Construction Engineering and Management 137(10): 843-852. http://dx.doi.org/10.1061/(ASCE)CO.1943-7862.0000288

Allen, J. E.; Self, A. 2008. Analysis of the integration of knowledge and novelty in creative engineering design, Proceedings of the Institution of Mechanical Engineers, ASCE Journal of Aerospace Engineering 222(G1): 127167.

Arslan, G. 2012. Web-based contractor evaluation system for mass-housing projects in Turkey, Journal of Civil Engineering and Management 18(3): 323-334. http://dx.doi.org/10.3846/13923730.2012.698892

Banaitienè, N.; Banaitis, A.; Kaklauskas, A.; Zavadskas, E. K. 2008. Evaluating the life cycle of a building: a multivariant and multiple criteria approach, Omega: the International Journal of Management Science 36(3): 429-441. http://dx.doi.org/10.1016/j.omega.2005.10.010

Barrow, L. 2006. Form Follows idea: ideation and CADCAM, in $1^{\text {st }}$ International Conference on Digital Architecture and Construction, September 19-21, Seoul, South Korea, $41-49$.

Bayart, J. B.; Bulle, C.; Deschenes, L.; Margni, M.; Pfister, S.; Vince, F.; Koehler, A. 2010. A framework for assessing off-stream freshwater use in LCA, International Journal of Life Cycle Assessment 15(5): 439-453.

http://dx.doi.org/10.1007/s11367-010-0172-7

Bhatla, A.; Choe, S. Y.; Fierro, O.; Leite, F. 2012. Evaluation of accuracy of as-built 3D modeling from photos taken by handheld digital cameras, Automation in Construction 28: 116-127. http://dx.doi.org/10.1016/j.autcon.2012.06.003

Bitarafan, M.; Hashemkhani Zolfani, S.; Arefi, S. L.; Zavadskas, E. K. 2012. Evaluating the construction methods of cold-formed steel structures in reconstructing the areas damaged in natural crises, using the methods AHP and COPRAS-G, Archives of Civil and Mechanical Engineering 12(3): 360-367.

http://dx.doi.org/10.1016/j.acme.2012.06.015
BLDG BLOG. 2012. The Robot and the Architect are Friends [online]. [Cited 12 June 2012] Available from Internet: http://bldgblog.blogspot.sg/2011/03/robot-and-architectare-friends.html

Boukhatem, B.; Kenai, S.; Tagnit-Hamou, A.; Ghrici, M. 2011. Application of new information technology on concrete: an overview, Journal of Civil Engineering and Management 17(2): 248-258.

Brühwiler, E. 2011. The new Swiss Codes for engineering of existing structures, Stahlbau 80(6): 379-388. http://dx.doi.org/10.1002/stab.201101437

Building SMART International. 2012. [Online], [cited 12 June 2012]. Available from Internet: www.buildingsmart.org

Castro-Lacouture, D.; Medaglia, A. L.; Skibniewski, M. 2007. Supply chain optimization tool for purchasing decisions in B2B construction marketplaces, Automation in Construction 16(5): 569-575. http://dx.doi.org/10.1016/j.autcon.2006.08.005

Chao, L-C.; Skibniewski, M. 1994. Estimating construction productivity: neural-network- based approach, Journal of Computing in Civil Engineering 8(2): 234-251. http://dx.doi.org/10.1061/(ASCE)0887-3801(1994)8: 2(234)

Chao, L-C.; Skibniewski, M. 1995. Decision analysis for new construction technology implementation, Civil Engineering Systems 12: 67-82. http://dx.doi.org/10.1080/02630259508970159

Cheng, T.; Teizer, J. 2011. 3D Immersive Data Visualization Technology for Real-time Construction Applications, in Conference Proceedings, Information Technologies in Safety Management (ITSM) of Large Scale Infrastructure Projects, 21-23 November, Huazhong University of Science and Technology, Wuhan, China.

Chow, P. T.; Cheung, S. O.; Yiu, T. W. 2010. A cusp catastrophe model of withdrawal in construction project dispute negotiation, Automation in Construction 22: 597-604. http://dx.doi.org/10.1016/j.autcon.2011.12.006

Chu, J.; Ivanov, V.; He, J.; Naeimi, M.; Li, B.; Stabnikov, V. 2011. Development of microbial geotechnology in Singapore, Geotechnical Special Publications 4070-4078.

Clements-Crowne, D. 2011. Sustainable intelligent buildings for people: a review, Intelligent Buildings International 3(2): 67-86.

Crane Accidents [online]. [Cited 12 June 2012]. Available from Internet: www.craneaccidents.com

Costa, A. A.; Tavares, L. V. 2012. Social e-business and the Satellite Network model: innovative concepts to improve collaboration in construction, Automation in Construction 22: 387-397. http://dx.doi.org/10.1016/j.autcon.2011.09.017

Construction Week online [online]. [Cited 13 June 2012]. Available from Internet: www.constructionweekonline.com/ article-16406-engineering-genius--towers

Construction Industry Institute [online]. [Cited 12 June 2012]. Available from Internet: https://www.constructioninstitute.org

Dejus, T. 2011. Safety of technological projects using multicriteria decision making methods, Journal of Civil Engineering and Management 17(2): 177-183.

Ediz, Ö.; Çagdas, G. 2007. A computational architectural design model based on fractals, Open House International (Special Issue on: Architecture in the Digital Age: The Effects of Digital Media on Built Environment) 32(2): 36-45. 
Fan, Z. 2009. Exploration and practice in design of spatial structure, in 3PR International Forum on Advances in Structural Engineering: Advances in Research and Practice of Steel Structures, 13-14 November, 2009, Shanghai, China, 466-481.

Fiatech [online]. [Cited 12 June 2012]. Available from Internet: www.fiatech.org

Fiedler, K.; Peldschus, F.; Zavadskas, E. 1981. Construction process theory - an important discipline, Statyba ir architektūra 10(269): 12-13 (in Lithuanian).

Gaultney, L.; Skibniewski, M.; Salvendy, G. 1989. A systematic approach to industrial technology transfer: a conceptual framework and a proposed methodology, Journal of Information Technology 4(1): 7-16. http://dx.doi.org/10.1057/jit.1989.2

Ghaffarian Hoseini, A. 2012. Ecologically sustainable design (ESD): theories, implementations and challenges towards intelligent building design development, Intelligent Buildings International 4(1): 34-48. http://dx.doi.org/10.1080/17508975.2011.630062

Gong, H.; Chen, C.; Bialostozky, E.; Lawson, C. T. 2012. A GPS/GIS method for travel mode detection in New York City, Computers, Environment and Urban Systems 36(2): 131-139.

http://dx.doi.org/10.1016/j.compenvurbsys.2011.05.003

Haas, C.; Skibniewski, M.; Budny, E. 1995. Robotics in Civil Engineering, Computer-Aided Civil and Infrastructure Engineering 10(5): 371-381.

http://dx.doi.org/10.1111/j.1467-8667.1995.tb00298.x

Hajdu, M. 1997. Network Scheduling Techniques for Construction Project Management, Nonconvex Optimization and Its Application Series. The Netherlands: Kluwer Academic Publishers.

Hartmann, T. 2011. Goal and process alignment during the implementation of decision support systems by project teams, Journal of Construction Engineering and Management 137(12): 1134-1141.

http://dx.doi.org/10.1061/(ASCE)CO.1943-7862.0000389

Historical Construction Equipment Association [online]. 2012. [Cited 11 June 2012]. Available from Internet: www.hcea.net

Holland, M. C. G. O. 2006. The Virtual school of Architecture and Design, in Proceedings, $I^{\text {st }}$ International Conference on Digital Architecture and Construction, 19-21 September, Seoul, South Korea, 121-129.

Ibrahim, R.; Rahimian, F. P. 2010. Comparison of CAD and manual sketching tools for teaching architectural design, Automation in Construction 19(8): 978-987.

http://dx.doi.org/10.1061/(ASCE)CO.1943-7862.0000389

International Association for Automation and Robotics in Construction [online]. 2012. [Cited 12 June 2012]. Available from Internet: www.iaarc.org

Jiang, S.; Jang W-S.; Skibniewski, M. J. 2012. Selection of wireless technology for tracking construction materials using a fuzzy decision model, Journal of Civil Engineering and Management 18(1): 43-59.

http://dx.doi.org/10.3846/13923730.2011.652157

Kaklauskas, A.; Zavadskas, E. K. 2002. Web-based decision support. Vilnius: Technika. 291 p. (in Lithuanian).

Kaklauskas, A.; Zavadskas, E. K. 2004. Some recommendations for the development of the Lithuanian construction sector. The construction sector system approach: an international framework: report by CIB W055-W065 "Construction industry comparative analysis" Project group, CIB Publication No. 293. Rotterdam: CIB. 114-134.

Kaklauskas, A.; Zavadskas, E. K. 2010. Support of biometric and intellectual solutions. Vilnius: Technika. $374 \mathrm{p}$. (in Lithuanian).

Kaklauskas, A.; Zavadskas, E. K. 2012. Biometricheskaia $i$ intellektual'naia podderzhka reshenij [Biometric and intelligent decision suport]: Monografiia. Vilnius: Technika. 344 p. (in Russian).

Kaklauskas, A.; Rute, J.; Gudauskas, R.; Banaitis, A. 2011. Integrated model and system for passive houses multiple criteria analysis, International Journal of Strategic Property Management 15(1): 74-90. http://dx.doi.org/10.3846/1648715X.2011.574903

Kaklauskas, A.; Zavadskas, E. K.; Naimavičienè, J.; Krutinis, M.; Plakys, V.; Venskus, D. 2010. Model for a complex analysis of intelligent built environment, Automation in Construction: An International Research Journal 19(3): 326-340. http://dx.doi.org/10.1016/j.autcon.2009.12.006

Kaklauskas, A.; Zavadskas, E. K. 2009. Theories of investment in property: use of information, knowledge and intelligent technologies, in Economics for the modern built environment. Les Ruddock (Ed.). Taylor \& Francis, 249-268.

Kaklauskas, A.; Kelpšienė, L.; Zavadskas, E. K.; Bardauskienė, D.; Kaklauskas, G.; Urbonas, M.; Sorakas, V. 2011. Crisis management in construction and real estate: conceptual modeling at the micro-, meso- and macro-levels, Land Use Policy 28(1): 280-293.

http://dx.doi.org/10.1016/j.landusepol.2010.06.008

Kaklauskas, A.; Zavadskas, E. K.; Bardauskiene, D.; Dargis, R. (Eds.). 2012. Sustainable real estate development. Vilnius: Technika. 877 p.

Kanapeckienė, L.; Kaklauskas, A.; Zavadskas, E. K.; Raslanas, S. 2011. Method and system for multi-attribute market value assessment in analysis of construction and retrofit projects, Expert Systems with Applications 38(11): 1419614207. http://dx.doi.org/10.1016/j.eswa.2011.04.232

Kicinger, R.; Arciszewski, T.; De Jong, K. A. 2005. Evolutionary computation and structural design: a survey of the state of the art, Computers \& Structures 83(23-24): 19431978. http://dx.doi.org/10.1016/j.compstruc.2005.03.002

Kocsis, T.; Hajdu, M.; Bokor, O. 2011. Challenges to the Construction Industry of Transition Countries, Budownictwo $i$ Inżynieria Środowiska [Civil and Environmental Engineering] 2: 521-526. Białystok University of Technology Publishers.

Koksalan, M.; Wallenius, J.; Zionts, S. 2011. Multiple criteria decision making: from early history to the 21st century. Singapore: World Scientific.

Lainez, J. M. C.; Verdejo, J. R. J.; Macias, B. S. M.; Calero, J. I. P. 2009. The Key-role of Eladio Dieste, Spain and the Americas in the evolution, Journal of Asian Architecture and Building Engineering 8(2): 355-362. http://dx.doi.org/10.3130/jaabe.8.355

Langford, D.; Dimitrijević, B. 2002. Construction creativity casebook. Thomas Telford Publishing, ASCE Press. http://dx.doi.org/10.1680/ccc.31487

Lee, G.; Cho, J.; Ham, S.; Lee, T.; Lee, G.; Yun, S.-H.; Yang, H.-J. 2012. A BIM- and sensor-based tower crane navigation system for blind lifts, Automation in Construction 26: 1-10. http://dx.doi.org/10.1016/j.autcon.2012.05.002

Li, H.; Guo, H.-L.; Skibniewski, M.; Skitmore, M. 2008. Using the IKEA model and virtual prototyping technology to 
improve construction process management, Construction Management and Economics 26(9): 991-1000. http://dx.doi.org/10.1080/01446190802290477

Liao, P. C.; Thomas, S. R.; O’Brien, W. J.; Dai, J.; Mulva, S. P.; Kim, I. 2012. Benchmarking project level engineering productivity, Journal of Civil Engineering and Management 18(2): 235-244.

http://dx.doi.org/10.3846/13923730.2012.671284

Mackechnie, J.; Buchanan, A. 2012. Creative laboratory model for large undergraduate engineering classes, Journal of Professional Issues in Engineering Education and Practice 138(1): 55-61.

http://dx.doi.org/10.1061/(ASCE)EI.1943-5541.0000081

Mann, S. 2006. Nanotechnology and construction, institute of nanotechnology [online]. 55 p. Available from Internet: www.nanoforum.org/dateien/temp/Nanotech\%20and\%20 Construction\%20Nanoforum\%20report.pdf? 09052012123958

Martí, I.; Vicente Ramón, T. L.; Luis Amable, G. F.; Martínez, J. J. 2012. A multi-agent system for managing adverse weather situations on the road network, Integrated ComputerAided Engineering 17(2): 145-155. http://dx.doi.org/10.3233/ICA-2010-0336

Marsh, E. 1975. The Harmonogram of Karol Adamiecki, Research Notes, The Academy of Management Journal 18(2): 358-364. http://dx.doi.org/10.2307/255537

Mashood, P.; Krishnamoorthy, C.; Ramamurthy, K. 2007. KBGA-Based hybrid system for layout planning of multistory buildings, Journal of Computing in Civil Engineering 21(4): 229-237. http://dx.doi.org/10.1061/(ASCE)08873801(2007)21:4(229)

Mukerji, C. 2005. The Politics of Rediscovery in the History of Science: Tacit Knowledge of Concrete before its Discovery, in Proceedings, American Sociological Association, Philadelphia, PA (USA), 12 August.

National Institute of Building Science. 2012. [Online], [cited 12 June 2012]. Available from Internet: www.wbdg.org/references/jbim.php

National Institute of Building Science. 2012.[Online], [cited 12 June 2012]. Available from Internet: www.buildingsmartalliance.org

Negoescu, F.; Axinte, E. 2007. Engineering for strategic advantages, in Branko Katalinic, Vienna University of Technology- Wien, Au (Eds.). Annals of Danube Adria Association for Automation \& Manufacturing for 2007, 499-500.

Nieto-Morote, A.; Ruz-Vila, F. 2012. A fuzzy multi-criteria decision-making model for construction contractor prequalification, Automation in Construction 25: 8-19. http://dx.doi.org/10.1016/j.autcon.2012.04.004

Nitithamyong, P.; Skibniewski, M. 2004. Web-based construction project management systems: what makes them succeed?, Automation in Construction 13(4): 491-506. http://dx.doi.org/10.1016/j.autcon.2004.02.003

Noor, A. K. 2011. Intelligent adaptive cyber-physical ecosystem for aerospace engineering education, training, and accelerated workforce development, Journal of Aerospace Engineering 24(4): 403-408. http://dx.doi.org/10.1061/(ASCE)AS.1943-5525.0000128

Pan, N.-H.; Lee, M.-L.; Chen, S.-Q. 2011. Construction material supply chain process analysis and optimization, Journal of Civil Engineering and Management 17(3): 357370. http://dx.doi.org/10.3846/13923730.2011.594221
Peldschus, F.; Zavadskas, E. K. 2012. Equilibrium approaches for construction processes - multi-objective decision making for construction projects, Bauingenieur 87: 210-215.

Podvezko, V.; Mitkus S.; Trinkuniene, E. 2010. Complex evaluation of contracts for construction, Journal of Civil Engineering and Management 16(2): 287-297. http://dx.doi.org/10.3846/jcem.2010.33

Popov, V.; Juocevicius, V.; Migilinskas, D.; Ustinovichius, L.; Mikalauskas, S. 2010. The use of a virtual building design and construction model for developing an effective project concept in 5D environment, Automation in Construction 19(3): 357-367.

http://dx.doi.org/10.1016/j.autcon.2009.12.005

Promis, G.; Gabor, A.; Hamelin, P. 2012. Effect of posttensioning on the bending behavior of mineral matrix composite beams, Construction and Building Materials 34: 442-450.

http://dx.doi.org/10.1016/j.conbuildmat.2012.02.028

Radziszewska Zielina, E. 2010. Methods for selecting the best partner construction enterprise in terms of partnering relations, Journal of Civil Engineering and Management 16(4): 510-520. http://dx.doi.org/10.3846/jcem.2010.57

Razavi, S. N.; Haas, C. 2012. A reliability-based hybrid data fusion method for adaptive location estimation in construction, ASCE Journal of Computing in Civil Engineering 26(1): 1-10. http://dx.doi.org/10.1061/(ASCE)CP.19435487.0000101

Russell, J.; Skibniewski, M. 1990. An ergonomic analysis framework for construction tasks, Construction Management and Economics 8(3): 329-338.

http://dx.doi.org/10.1080/01446199000000027

Salman, A.; Skibniewski, M.; Basha, I. 2007. BOT viability model for large scale infrastructure projects, $A S C E$ Journal of Construction Engineering and Management 33(1): 50-63. http://dx.doi.org/10.1061/(ASCE)07339364 (2007)133:1(50)

Sarrade, L.; Manficat, A.; Corgier, D.; Burgun, V. F. 2007. The GENHEPI concept: a new methodology for low energy consumption building renovation and demonstration program, Strojarstvo 49(3): 241-247.

Sawaf, A.; Skibniewski, M. 2011. Concepts for next generation smart real estate, Ekonomia i Zarzadzanie - Economics and Management 3(4): 169-177.

Schug, J.; Watson, A. 2012. Innovation: fostering creativity in the construction industry [online]. [Cited 12 June 2012]. Available from Internet: www.fminet.com/media/pdf/ quarterly/2012_1_foster_creativity.pdf

Seghedin, N. 2007. Combinatorics in Technical Creation, in Annals of DAAAM for 2007 and Proceeding of the 18th International DAAAM Symposium Intelligent Manufacturing \& Automation: Focus on Creativity, Responsibility and Ethics of Engineers, October 2007, Zadar, Croatia, Vienna: DAAAM International, 681-682.

Skibniewski, M. 1988a. Robotics in civil engineering. Southampton, Boston, New York: Computational Mechanics Publications/Van Nostrand Reinhold.

Skibniewski, M. 1988b. A framework for decision making on implementing robotics in construction, ASCE Journal of Computing in Civil Engineering 2(2): 188-201. http://dx.doi.org/10.1061/(ASCE)0887-3801(1988)2: 2(188) 
Skibniewski, M. 1993. On the implementation of industrial robotics in the construction industry [online], Inżynieria $i$ Budownictwo [Engineering and Construction, Journal of Polish Association of Civil Engineers and Civil Engineering Technologists] (12): 535-536 (in Polish). [Cited 13 June 2012]. Available from Internet: www.inzynieriaibudownictwo.pl

Skibniewski, M.; Arciszewski, T.; Lueprasert, K. 1997. Constructability analysis: machine learning approach, $A S C E$ Journal of Computing in Civil Engineering 11(1): 8-16. http://dx.doi.org/10.1061/(ASCE)0887-3801(1997)11: $1(8)$

Skibniewski, M. 2012. Creativity in Construction: a look at the past and a peak into the future, in Proceedings, Creative Construction 2012 Conference, 30 June - 3 July, 2012, Szent Istvan University Ybl Miklos Faculty, Budapest, Hungary (invited keynote paper), 629-635.

Skibniewski, M. J.; Jang, W.-S. 2009. Simulation of accuracy performance for wireless sensor-based construction asset tracking, Computer-Aided Civil and Infrastructure Engineering 24(5): 335-345. http://dx.doi.org/10.1111/j. 1467-8667.2009.00592.x

Skibniewski, M.; Nof, S. 1989. A framework for programmable and flexible construction systems, Robotics and Autonomous Systems 5: 135-150. http://dx.doi.org/10.1016/09218890(89)90006-7

Skibniewski, M.; Chao, L.-C. 1992. Evaluation of advanced construction technologies with analytical hierarchy process, ASCE Journal of Construction Engineering and Management 118(3): 577-593. http://dx.doi.org/10.1061/(ASCE)0733-9364(1992)118: $3(577)$

Grote, K.-H.; Antonsson, E. K. (Eds.). 2009. Springer Handbook of Mechanical Engineering. http://dx.doi.org/10.1007/978-3-540-30738-9

Srdic, A.; Šelih, J. 2011. Integrated quality and sustainability assessment in construction: a conceptual model, Technological and Economic Development of Economy 17(4): 611-626. http://dx.doi.org/10.3846/20294913.2011.603177

Tchidi, M.; He, Z.; Li, Y-B. 2012. Process and quality improvement using six sigma in construction industry, Journal of Civil Engineering and Management 18(2): 158-172. http://dx.doi.org/10.3846/13923730.2012.657411

The Construction Innovation Forum (CIF) [online]. [Cited 12 June 2012]. Available from Internet: www.cif.org

Turskis, Z.; Lazauskas, M.; Zavadskas, E. K. 2012. Fuzzy multiple criteria assessment of construction site alternatives for non-hazardous waste incineration plant in Vilnius city, applying ARAS-F and AHP methods, Journal of Environmental Engineering and Landscape Management 20(2): 110-120.

http://dx.doi.org/10.3846/16486897.2011.645827

Urbanavičienė, V.; Kaklauskas, A.; Zavadskas, E. K.; Seniut, M. 2009. The web-based real estate multiple criteria negotiation decision support system: a new generation of decision support systems, International Journal of Strategic Property Management 13(3): 267-286.

http://dx.doi.org/10.3846/1648-715X.2009.13.267-286

Wikipedia, the free encyclopedia. 2012. Technology [online]. [Cited 11 October 2012]. Available from Internet: http://en.wikipedia.org/wiki/Technology

Wikipedia, the free encyclopedia. 2012. [online], [cited 11 June 2012]. Available from Internet: http://en.wikipedia.org/wiki/Creativity
Yang, L.-R.; Chen, J.-H.; Wang, H.-W. 2012. Assessing impacts of information technology on project success through knowledge management practice, Automation in Construction 22: 182-191.

http://dx.doi.org/10.1016/j.autcon.2011.06.016

Yang, S.-Q.; Lin, P. 2011. Coastal reservoir by soft-dam and its possible applications, Recent Patents on Engineering 5(1): 45-56. http://dx.doi.org/10.2174/1872212111105010045

Yu, W. D.; Skibniewski, M. J. 1999. A neuro-fuzzy computational approach to constructability knowledge acquisition for construction technology evaluation, Automation in Construction 8: 539-552. http://dx.doi.org/10.1016/S0926-5805(98)00104-6

Zalama, E.; Gómez-García-Bermej, J.; Llamas, J.; Medina, R. 2011. An effective texture mapping approach for $3 \mathrm{D}$ models obtained from laser scanner data to building documentation, Computer-Aided Civil and Infrastructure Engineering 26(5): 381-392.

http://dx.doi.org/10.1111/j.1467-8667.2010.00699.x

Zavadskas, E. K. 1991. Systemotechnical evaluation of construction technology processes. Leningrad: Strojizdat (in Russian).

Zavadskas, E. K.; Karablikovas, A.; Kriukelis, V.; Nakas, M.; Sakalauskas, R. 2007. Building construction technology. Vilnius: Technika (in Lithuanian).

Zavadskas, E.; Kapliński, O.; Kaklauskas, A.; Brzeziński, J. 1995. Expert systems in construction industry: trends, potentials and applications. Vilnius: Technika.

Zavadskas, E. K. 2010. Automation and robotics in construction: international research and achievements: review: 25th International Symposium on Automation and Robotics in Construction, Automation in Construction 19(3): 286-290. http://dx.doi.org/10.1016/j.autcon.2009.12.011

Zavadskas, E. K.; Peldschus, F.; Kaklauskas, A. 1994. Multiple criteria evaluation of project in construction. Vilnius: Technika.

Zavadskas, E. K.; Kaklauskas, A. 2007. Mehrzielselektion für Entscheidungen im Bauwesen. Stuttgart: Fraunhofer IRB Verlag.

Zavadskas, E.; Kaklauskas, A.; Raslanas, S.; Galiniene, B. 2008. Web-based intelligent DSS for real estate, International Journal of Environment and Pollution 35(2-4): 250-264. http://dx.doi.org/10.1504/IJEP.2008.021359

Zavadskas, E. K.; Vaidogas, E.-R. 2009. Multiattribute selection from alternative designs of infrastructure components for accidental situations, Computer-Aided Civil and Infrastructure Engineering 24(5): 346-358. USA: WileyBlackwell Publishing. http://dx.doi.org/10.1111/j. 1467-8667.2009.00593.x

Zavadskas, E. K.; Turskis, Z.; Tamosaitiene, J. 2011. Selection of construction enterprises management strategy based on the SWOT and multi-criteria analysis, Archives of Civil and Mechanical Engineering 11(4): 1063-1082. http://dx.doi.org/10.1016/S1644-9665(12)60096-X

Zavadskas, E. K.; Turskis, Z. 2011. Multiple criteria decision making (MCDM) methods in economics: an overview, Technological and Economic Development of Economy 17(2): 397-427.

http://dx.doi.org/10.3846/20294913.2011.593291

Zavadskas, E. K.; Kaklauskas, A.; Banaitis, A. 2011. The use of the intelligent library and tutoring system at all stages of a building life cycle, Inzinerine Ekonomika - Engineering Economics 22(1): 14-23. 
Zhang, J. P.; Hu, Z. Z. 2011. BIM- and 4D-based integrated solution of analysis and management for conflicts and structural safety problems during construction: 1 . Principles and methodologies, Automation in Construction 20(2): 155-166.

http://dx.doi.org/10.1016/j.autcon.2010.09.013

Zheng, W.; Shih, H.; Lozano, K.; Mo, Y. 2011. Impact of nanotechnology on future civil engineering practice and its reflection in current civil engineering education, Journal of Professional Issues in Engineering Education and Practice 137(3): 162-173.

http://dx.doi.org/10.1061/(ASCE)EI.1943-5541.0000034
2012 and 2013 International Symposia on Automation and Robotics in Construction [online]. 2012. [Cited 20 June 2012]. Available from Internet:

www.futuresiteconferences.nl/index.php/isg-isarc/ ISGISARC2012; https://www.isarc2013.org

Mirosław J. SKIBNIEWSKI. Professor of Construction Engineering and Project Management at the University of Maryland (College Park), USA. A past winner of the U.S. National Science Foundation Presidential Young Investigator Award, the Walter L. Huber Research Prize from the American Society of Civil Engineers and a foreign member of the Russian Academy of Engineering. A holder of an honorary doctorate from Vilnius Gediminas Technical University in Lithuania. An author or co-author of over 200 technical publications. Research interests include automation and information technology issues related to construction project engineering and management.

Edmundas K. ZAVADSKAS. Professor and Head of the Department of Construction Technology and Management at Vilnius Gediminas Technical University, Vilnius, Lithuania, and the Founding Rector/President of the same institution. Member of the Lithuanian and several foreign Academies of Sciences. Holder of honorary doctorates from Poznań, Saint Petersburg, and Kiev technical universities. An author or co-author of over 400 scholarly papers and a number of monographs on construction technologies and management. Research interests include construction technology and management, decision-making theory, automation in design and decision support systems. 